\title{
Variation in the CXCR1 gene (IL8RA) is not associated with susceptibility to chronic periodontitis
}

\author{
Raquel M Scarel-Caminaga ${ }^{1 *}$, Karen MC Curtis ${ }^{1}$, Rivelto Renzi ${ }^{1}$, Patrícia M Sogumo', Giovana Anovazzi ${ }^{1,2}$, \\ Aline C Viana ${ }^{2}$, Yeon J Kim², Silvana RP Orrico ${ }^{2}$ and Joni A Cirelli ${ }^{2}$
}

\begin{abstract}
Background: The chemokine receptor 1 CXCR-1 (or IL8R-alpha) is a specific receptor for the interleukin 8 (IL-8), which is chemoattractant for neutrophils and has an important role in the inflammatory response. The polymorphism rs2234671 at position Ex2+860G > C of the CXCR1 gene causes a conservative amino acid substitution (S276T). This single nucleotide polymorphism (SNP) seemed to be functional as it was associated with decreased lung cancer risk. Previous studies of our group found association of haplotypes in the IL 8 and in the CXCR2 genes with the multifactorial disease chronic periodontitis. In this study we investigated the polymorphism rs2234671 in 395 Brazilian subjects with and without chronic periodontitis.
\end{abstract}

Findings: Similar distribution of the allelic and genotypic frequencies were observed between the groups ( $p>$ 0.05).

Conclusions: The polymorphism rs2234671 in the CXCR1 gene was not associated with the susceptibility to chronic periodontitis in the studied Brazilian population.

Keywords: CXCR1, chemokine, cytokine, genetic polymorphism, periodontal disease

\section{Findings}

The human chemokine receptor CXCR-1 (or IL8R-alpha) is a specific receptor for the chemokine interleukin 8 (IL-8) [1]. Initially identified as a chemoattractant for neutrophils, IL-8 has been demonstrated to have pro-inflammatory effects including stimulation of neutrophil degranulation [2]. Cellular activities of IL-8 are mediated by CXCR-1 and CXCR-2 (IL8R-beta), which maintain $78 \%$ of amino acid similarity and are encoded by two single-copy genes that are located on chromosome 2q34-35 [3]. However, CXCR1 is more specific for IL-8 in comparison with CXCR-2 [4].

The involvement of IL-8, CXCR-1 and CXCR-2 has been extensively investigated in different diseases such as pyelonephritis [5,6], hepatitis B [7], rapid disease progression of $\mathrm{HIV}-1^{+}$[8], lung diseases, such as chronic obstructive pulmonary disease and asthma [9], bronchiectasis [10], systemic sclerosis [11] and lung cancer [12]. Some of these studies have reported positive associations between the

\footnotetext{
* Correspondence: raquel@foar.unesp.br

'UNESP - São Paulo State University, School of Dentistry at Araraquara,

Department of Morphology, SP, Brazil

Full list of author information is available at the end of the article
}

diseases and single nucleotide polymorphisms (SNPs) in the $C X C R 1$ gene $[8,9]$. Indeed, a significant association was demonstrated between the 860G > C (S276T) SNP in the CXCR1 gene with decreased lung cancer risk [12]. Haplotypes formed by SNPs in the CXCR1 and CXCR2 genes where also previously identified [7].

The 860G > C (S276T) SNP in CXCR1 gene was identified by comparison of multiple sequences deposited in the GenBank/EMBL data banks [11,13]. These authors named this polymorphism differently: +2607 (position 6334 of sequence accession number [GenBank: L19592.1]) in exon 2 , and +827 (starting from the initiation of the ATG codon in exon 2 of [GenBank: L19592.1]), respectively. The variant position $860 \mathrm{G}>\mathrm{C}$ is based on the [NCBI: NM000634.2] exon 2 initiations, however it is important to be clear that all these different positions at the CXCR1 gene refer to the same polymorphism $(\mathrm{G}>\mathrm{C})$, which results in a conservative amino acid substitution from serine to threonine at the 276 amino acid residue of the CXCR-1 (or IL8R-alpha) protein. Here, we preferred to use the reference sequence number [refSNP ID:

\section{(Ciomed Central}


rs2234671] in NCBI's Entrez system (http://www.ncbi.nlm. nih.gov/SNP).

Predominantly in the last decade, many candidate-gene investigations have been conducted in order to find genetic risk factors associated with chronic periodontitis (CP). Epidemiological studies indicate that $\mathrm{CP}$ is an important cause of teeth loss in adults, since $5 \%$ to $15 \%$ of any population suffers from this disease [14]. CP is a multifactorial disease, initiated by bacterial infection which can progress to the damage and destruction of the supporting tissues of the teeth [15]. The host response is influenced by both environmental (e.g. smoking, oral hygiene) and genetic factors [16]. Some studies have demonstrated association between polymorphisms in genes of the immune system and CP, such as Interleukin 2 (IL2) [17,18], IL4 [19-21], IL6 [22,23] and IL10 [24,25]. Recently, we have reported association between haplotypes in the IL8 and in the CXCR2 genes with CP [26,27]. Because those previous findings and the biological relationship of the CXCR-1 with the IL-8 and the CXCR-2 [1,5] we have hypothesized whether a SNP in the CXCR1 gene would also influence the host susceptibility to $\mathrm{CP}$.

In this regard, the aim of this study was to investigate the association of the rs2234671 SNP in the CXCR1 gene in a Brazilian population with chronic periodontitis.

\section{Materials and methods}

In total, 395 individuals in good general health and having similar socioeconomic status were recruited from the patient pool of the School of Dentistry at Araraquara, São Paulo State University - UNESP between November 2004 and May 2007. The study was approved by the Committee for Ethical Affairs of the São Paulo State University (Protocol number 57/04).

To verify statistical power of our sample, we used the G*POWER 3 software [28] with the following parameters: logistic regression; two tail, odds ratio $=1.56, \alpha$ error probability $=0.05$. Detailed clinical criteria for include patients in this study are described in Viana et al. [27]. Briefly, the following clinical signs and parameters were assessed at six sites around each tooth: probing pocket depth (PPD) (measured as distance from the free gingival margin to the base of the pocket), clinical attachment loss (CAL) (as the distance from the cement-enamel junction to the base of the periodontal pocket) and bleeding on probing (BOP) (registered as present or absent). These measurements were performed in millimeters using a periodontal probe with Williams markings. All fully erupted teeth, except third molars and retained roots, were examined. The diagnosis of subjects was established on the basis of clinical criteria proposed by the 1999 International World Workshop for a Classification of Periodontal Diseases and Conditions [29]. The subjects were categorized into two groups: controls $(\mathrm{n}=191)$, subjects exhibiting no sites with CAL and PPD $\geq 3 \mathrm{~mm}$ and no BOP; and CP $(n=200)$, subjects exhibiting one or more sites with CAL and PPD $\geq 3 \mathrm{~mm}$ and BOP.

Information on smoking status was obtained using a self-reported questionnaire, and subjects were classified as a "smoker" or "nonsmoker" according to Kornman et al. [30].

DNA was obtained from buccal epithelial cells, extracted with sequential phenolchloroform/isoamyl alcohol $(25: 24: 1)$ solution and precipitated with a salt ethanol solution. The SNP was identified using the sequence-specific primer-polymerase chain reaction method (SSP-PCR) according to Renzoni et al. [11]. The PCR products were electrophoresed (100 V, $120 \mathrm{~min})$ in $10 \%$ polyacrylamide gels and visualized by silver staining.

The chi-squared test was used to determine whether the groups were composed of patients with the same proportion of males and females and whether they had similar smoking habits. Onset age distribution between the two groups was evaluated by Students't-test. Those statistical analyses, as well as deviations from Hardy-Weinberg equilibrium, were performed using BioEstat software version 5.0 (UFPA, MCT, CNPq, Belém, PA, Brazil).

In addition, a forward stepwise multiple logistic regression analysis was used for estimating the relationships between the SNP rs2234671 in the CXCR1gene and periodontal disease susceptibility and the other covariates. This multivariate logistic regression modeling was executed using the $\mathrm{R}$ statistical package ( $\mathrm{R}$ Development Core Team, Vienna, Austria). Differences were considered to be significant when $\mathrm{p}<0.05$.

\section{Results}

The power calculations showed that the sample size of 395 individuals demonstrated a power of $93 \%$. Therefore, the number of subjects enrolled in this study is large enough to detect association with an acceptable level of confidence. The population investigated here was composed mainly of female subjects (59.7\%) and nonsmokers $(84.8 \%)$ and the mean age of the individuals was 39.49 years (Table 1). The minor allele frequency (MAF) was 0.087 , and the genotype distribution of the rs2234671 SNP in the CXCR1 gene was consistent with the assumption of the Hardy-Weinberg equilibrium for the control $(\mathrm{p}=0.1719)$ and $\mathrm{CP}$ groups $(p=0.2777)$.

Significant associations between age and periodontitis were observed by univariate analysis, mainly considering the ORs for age groups 30-39 to the 50-59. We consider that besides the 60-69 and $>70$ age groups showed significant OR values they were uncommon and demonstrated a wide range of CI. Significant association was also found between smoking status and periodontitis $(\mathrm{OR}=3.8)$. Therefore, age and smoking status were considered 
Table 1 Characteristics of the studied populations

\begin{tabular}{|c|c|c|c|c|}
\hline & Control $n=195$ & Periodontitis $n=200$ & Total $\mathrm{n}=395$ & $p$ \\
\hline Age, mean $( \pm)$ & $35.47( \pm 9.9)$ & $43.44( \pm 10.5)$ & $39.49( \pm 10.9)$ & $<0.0001^{\mathrm{a}}$ \\
\hline \multicolumn{5}{|l|}{ Gender n (\%) } \\
\hline Female & $114(58 \%)$ & $122(61 \%)$ & $236(59.7 \%)$ & $0.74^{\mathrm{b}}$ \\
\hline Male & 81 (42\%) & 78 (39\%) & $159(40.3 \%)$ & \\
\hline \multicolumn{5}{|c|}{ Smoking habits n (\%) } \\
\hline Nonsmokers & 179 (91\%) & $156(78 \%)$ & $335(84.8 \%)$ & $<0.0002^{\mathrm{b}}$ \\
\hline Smokers & $16(9 \%)$ & $44(22 \%)$ & 60 (15.2\%) & \\
\hline
\end{tabular}

${ }^{\text {a }}$ Student t-test; ${ }^{\text {b } C h i-s q u a r e d ~ t e s t ~}$

confounding factors. Even though gender was not found to be associated with periodontitis, we included it in the confounding factors in the multivariate analysis, to adjust for any small confounding effects. To more accurately evaluate the strength of any association and to eliminate the distortion caused by confounding effects, multivariate analysis was performed. The multiple logistic regression analysis demonstrated that neither genotypes nor alleles were associated with periodontitis, even after adjusting for covariates, including age, gender and smoking status (Table 2). Therefore, this polymorphism could not be considered a genetic risk for CP in the studied Brazilian population.

\section{Discussion}

To our knowledge, this is the first time that the rs2234671 SNP in the CXCR1 gene was investigated regarding the $\mathrm{CP}$. Single nucleotide polymorphisms are mainly useful in studies of human population genetics and candidate-gene studies for disease association [31]. This makes possible the development of the susceptibility profile concept for specific diseases, like the risk of Alzheimer's, which has been considered to be substantially influenced by a total of ten genetic polymorphisms of inflammation-related molecules [32]. If the high-susceptibility profile for $\mathrm{CP}$ be determined, genetically susceptible subjects would be identified earlier and therapeutic intervention strategies could be envisaged aiming prevention of disease establishment. However, many studies with different populations would be needed to reach a high-risk profile for periodontal disease [16].

Another important point to be considered in studying genetic variations is about the functionality of a polymorphism. Considering that the rs2234671 SNP causes a conservative amino acid substitution (S276T) in the third extracellular loop of the CXCR-1 protein, one can suppose

Table 2 Regression logistic results of the analysis

\begin{tabular}{|c|c|c|c|c|c|}
\hline \multicolumn{2}{|c|}{ Characteristics of patients } & \multirow{2}{*}{$\begin{array}{c}\text { Control } \\
\mathbf{n}=195(\%)\end{array}$} & \multirow{2}{*}{$\begin{array}{c}\text { Periodontitis } \\
\mathbf{n}=\mathbf{2 0 0}(\%)\end{array}$} & \multirow[t]{2}{*}{ P-Value } & \multirow{2}{*}{$\begin{array}{c}\text { OR (95\% Cl) } \\
\text { Reference }\end{array}$} \\
\hline Age & $20-29$ & & & & \\
\hline & $30-39$ & $59(51.75)$ & $55(48.25)$ & $7.73 e-05$ & $3.47(1.82-6.63)$ \\
\hline & $40-49$ & $48(37.21)$ & $81(62.79)$ & $5.89 \mathrm{e}-10$ & $6.42(3.4-12.1)$ \\
\hline & $50-59$ & 13(30.96) & $29(69.04)$ & $1.14 \mathrm{e}-07$ & $8.46(3.64-19.63)$ \\
\hline & $60-69$ & 2(14.29) & $12(85.71)$ & $4.94 \mathrm{e}-07$ & $23.3(5.19-104.65)$ \\
\hline & $>70$ & $1(20)$ & $4(80)$ & $3.67 e-03$ & $13.77(1.67-113.32)$ \\
\hline \multirow[t]{2}{*}{ Gender } & Male & $81(50.94)$ & $78(49.06)$ & & Reference \\
\hline & Female & $114(48.31)$ & $122(51.69)$ & 0.65 & $1.11(0.7-1.74)$ \\
\hline \multirow[t]{2}{*}{ Smoking habits } & Nonsmokers & $179(53.42)$ & $156(46.58)$ & & Reference \\
\hline & Smokers & $16(26.67)$ & $44(73.33)$ & $2.203134 \mathrm{e}-05$ & $3.8(1.97-7.33)$ \\
\hline \multirow{5}{*}{$\begin{array}{l}\text { Polymorphism } \\
\text { rs2234671 }\end{array}$} & GG & $164(84.1)$ & $166(83.3)$ & & Reference \\
\hline & CG & $28(14.4)$ & $31(15.5)$ & 0.55 & $1.2(0.65-2.2)$ \\
\hline & $\mathrm{CC}$ & $3(1.5)$ & $3(1.5)$ & 0.89 & $1.13(0.18-7.27)$ \\
\hline & G & $356(91.3)$ & $363(90.8)$ & & Reference \\
\hline & C & $34(8.7)$ & 37 (9.2) & 0.52 & $1.21(0.68-2.15)$ \\
\hline
\end{tabular}


whether this event would influence the ligand/binding interaction of the chemokine receptor. This speculation was raised by Liu and colleagues [33], which found four SNPs (including the rs2234671) in human populations, that were not found in nonhuman primate species when the gene sequences were compared. The authors concluded that there is an accelerated CXCR-1 protein evolution in the human lineage. However, more studies are necessary in order to clarify whether this SNP is functional, and whether it would be under selective pressure aiming to improve innate immunity.

Relevant factors known to influence the pathogenesis of periodontitis were assessed by multivariate analysis. Regarding age, there is evidence that both the prevalence and severity of periodontitis increase with increasing age [34]. This can be explained by the cumulative effect of prolonged exposure to other risk factors [35]. There is a multitude of studies (more than 325) that have shown a relationship between smoking and periodontitis [36]. In the present study, smoking was found as a risk factor for periodontitis (OR $=3.8,95 \% \mathrm{CI}$ : 1.97-7.33). Interestingly, Tonetti et al. [37] reported that cigarette smoking is associated with two- to threefold increases in the odds of developing periodontitis. Also similar with our results, Tomar \& Asma [38] found that current smokers were about four times as likely to have periodontitis than persons who never smoked, after adjusting for covariates such as age, gender and education. Some studies have shown that smokers had significantly worse clinical symptoms of periodontitis than non-smokers [39,40].

We did not take into account ancestry in our study because we only obtained the skin color information. Although Brazilian population is admixtured, the skin color is not related with ancestry according to Pena et al. [41], Parra et al. [42] and Pimenta et al. [43].

In regards to our hypothesis whether the rs2234671 SNP in the CXCR1 gene would be associated with susceptibility to chronic periodontitis, the obtained results showing a lack of association permit us to conclude that this SNP was not useful as a genetic risk factor for CP in the studied Brazilian population.

\section{Abbreviations}

IL-8: Interleukin 8; SNP: Single Nucleotide Polymorphism; CP: Chronic Periodontitis; PPD: Probing Pocket Depth; CAL: Clinical Attachment Loss; BOP: Bleeding on Probing.

\section{Acknowledgements}

This study was supported by CAPES and FAPESP grants (03/10424-0, 06/ 04492-1, 05/03231-7, 2005/04553-8).

\section{Author details}

'UNESP - São Paulo State University, School of Dentistry at Araraquara, Department of Morphology, SP, Brazil. '2UNESP - São Paulo State University, School of Dentistry at Araraquara, Department of Oral Diagnosis and Surgery, SP, Brazil.

\section{Authors' contributions}

RMSC conceived and coordinated the study, performed statistical analysis and wrote the manuscript. KMCC, RR, PMS: carried out the molecular reactions and helped analyze the results. GA: helped with the statistical analysis and helped wrote the manuscript. ACV, YJK: examined and selected the patients and extracted the DNA. SRPO, JAC: participated in the study design, defined the clinical criteria of the studied groups and helped wrote the manuscript. All authors read and approved the final manuscript.

\section{Competing interests}

The authors declare that they have no competing interests.

Received: 26 May 2011 Accepted: 3 November 2011

Published: 3 November 2011

\section{References}

1. Baggiolini M: Chemokines and leukocyte traffic. Nature 1998, 392(6676):565-568.

2. Holmes WE, Lee J, Kuang WJ, Rice GC, Wood WI: Structure and functional expression of a human interleukin-8 receptor. Science 1991, 253(5025):1278-1280.

3. Morris SW, Nelson N, Valentine MB, Shapiro DN, Look AT, Kozlosky CJ, Beckmann MP, Cerretti DP: Assignment of the genes encoding human interleukin-8 receptor types 1 and 2 and an interleukin-8 receptor pseudogene to chromosome 2q35. Genomics 1992, 14(3):685-691.

4. Lee J, Horuk R, Rice GC, Bennett GL, Camerato T, Wood Wl: Characterization of two high affinity human interleukin-8 receptors. J Biol Chem 1992, 267(23):16283-16287.

5. Frendeus B, Godaly G, Hang L, Karpman D, Svanborg C: Interleukin-8 receptor deficiency confers susceptibility to acute pyelonephritis. J Infect Dis 2001, 183(Suppl 1):S56-60.

6. Artifoni L, Negrisolo S, Montini G, Zucchetta P, Molinari PP, Cassar W, Destro R, Anglani F, Rigamonti W, Zacchello G, et al: Interleukin-8 and CXCR1 receptor functional polymorphisms and susceptibility to acute pyelonephritis. J Urol 2007, 177(3):1102-1106.

7. Cheong JY, Cho SW, Choi JY, Lee JA, Kim MH, Lee JE, Hahm KB, Kim JH: RANTES, MCP-1, CCR2, CCR5, CXCR1 and CXCR4 gene polymorphisms are not associated with the outcome of hepatitis $B$ virus infection: results from a large scale single ethnic population. J Korean Med Sci 2007, 22(3):529-535.

8. Vasilescu A, Terashima Y, Enomoto M, Heath S, Poonpiriya V, Gatanaga H, Do H, Diop G, Hirtzig T, Auewarakul P, et al: A haplotype of the human CXCR1 gene protective against rapid disease progression in HIV-1+ patients. Proc Natl Acad Sci USA 2007, 104(9):3354-3359.

9. Stemmler S, Arinir U, Klein W, Rohde G, Hoffjan S, Wirkus N, ReinitzRademacher K, Bufe A, Schultze-Werninghaus G, Epplen JT: Association of interleukin-8 receptor alpha polymorphisms with chronic obstructive pulmonary disease and asthma. Genes Immun 2005, 6(3):225-230.

10. Boyton RJ, Reynolds C, Wahid FN, Jones MG, Ozerovitch L, Ahmad T, Chaudhry A, Jewell DP, Kon OM, Smith J, et al: IFN gamma and CXCR-1 gene polymorphisms in idiopathic bronchiectasis. Tissue Antigens 2006, 68(4):325-330.

11. Renzoni E, Lympany $P$, Sestini $P$, Pantelidis $P$, Wells $A$, Black C, Welsh $K$, Bunn C, Knight C, Foley $P$, et al: Distribution of novel polymorphisms of the interleukin-8 and CXC receptor 1 and 2 genes in systemic sclerosis and cryptogenic fibrosing alveolitis. Arthritis Rheum 2000, 43(7):1633-1640.

12. Lee KM, Shen M, Chapman RS, Yeager M, Welch R, He X, Zheng T, Hosgood HD, Yang D, Berndt SI, et al: Polymorphisms in immunoregulatory genes, smoky coal exposure and lung cancer risk in Xuan Wei, China. Carcinogenesis 2007, 28(7):1437-1441.

13. Kato H, Tsuchiya N, Tokunaga K: Single nucleotide polymorphisms in the coding regions of human CXC-chemokine receptors CXCR1, CXCR2 and CXCR3. Genes Immun 2000, 1(5):330-337.

14. Burt B: Position paper: epidemiology of periodontal diseases. $J$ Periodontol 2005, 76(8):1406-1419.

15. Loos BG, John RP, Laine ML: Identification of genetic risk factors for periodontitis and possible mechanisms of action. J Clin Periodontol 2005, 32(Suppl 6):159-179.

16. Kinane DF, Hart TC: Genes and gene polymorphisms associated with periodontal disease. Crit Rev Oral Biol Med 2003, 14(6):430-449. 
17. Scarel-Caminaga RM, Trevilatto PC, Souza AP, Brito RB, Line SR: Investigation of an IL-2 polymorphism in patients with different levels of chronic periodontitis. J Clin Periodontol 2002, 29(7):587-591.

18. Reichert S, Machulla HK, Klapproth J, Zimmermann U, Reichert Y, Glaser C, Schaller HG, Schulz S: Interleukin-2 -330 and 166 gene polymorphisms in relation to aggressive or chronic periodontitis and the presence of periodontopathic bacteria. J Periodontal Res 2009, 44(5):628-635.

19. Scarel-Caminaga RM, Trevilatto PC, Souza AP, Brito RB, Line SR: Investigation of IL4 gene polymorphism in individuals with different levels of chronic periodontitis in a Brazilian population. $J$ Clin Periodontol 2003, 30(4):341-345.

20. Gonzales JR, Mann M, Stelzig J, Bodeker RH, Meyle J: Single-nucleotide polymorphisms in the IL-4 and IL-13 promoter region in aggressive periodontitis. J Clin Periodontol 2007, 34(6):473-479.

21. Anovazzi G, Kim YJ, Viana AC, Curtis KM, Orrico SR, Cirelli JA, ScarelCaminaga RM: Polymorphisms and haplotypes in the interleukin-4 gene are associated with chronic periodontitis in a Brazilian population. $J$ Periodontol 2010, 81(3):392-402

22. Trevilatto PC, Scarel-Caminaga RM, de Brito RB, de Souza AP, Line SR: Polymorphism at position -174 of IL-6 gene is associated with susceptibility to chronic periodontitis in a Caucasian Brazilian population. J Clin Periodontol 2003, 30(5):438-442.

23. Nibali L, Donos N, Farrell S, Ready D, Pratten J, Tu YK, D'Aiuto F: Association between interleukin-6 -174 polymorphism and Aggregatibacter actinomycetemcomitans in chronic periodontitis. J Periodontol 2010, 81(12):1814-1819.

24. Scarel-Caminaga RM, Trevilatto PC, Souza AP, Brito RB, Camargo LE, Line SR: Interleukin 10 gene promoter polymorphisms are associated with chronic periodontitis. J Clin Periodontol 2004, 31(6):443-448.

25. Cullinan MP, Westerman B, Hamlet SM, Palmer JE, Faddy MJ, Seymour GJ, Middleton PG, Taylor JJ: Progression of periodontal disease and interleukin-10 gene polymorphism. J Periodontal Res 2008, 43(3):328-333.

26. Scarel-Caminaga RM, Kim YJ, Viana AC, Curtis KM, Corbi SC, Sogumo PM, Orrico SR, Cirelli JA: Haplotypes in the interleukin 8 gene and their association with chronic periodontitis susceptibility. Biochem Genet 2011, 49(5-6):292-302.

27. Viana AC, Kim YJ, Curtis KM, Renzi R, Orrico SR, Cirelli JA, ScarelCaminaga RM: Association of haplotypes in the CXCR2 gene with periodontitis in a Brazilian population. DNA Cell Bio/ 2010, 29(4):191-200.

28. Faul $F$, Erdfelder $E$, Lang $A G$, Buchner $A$ : $G *$ Power 3: a flexible statistical power analysis program for the social, behavioral, and biomedical sciences. Behav Res Methods 2007, 39(2):175-191.

29. Armitage GC: Development of a classification system for periodontal diseases and conditions. Ann Periodontol 1999, 4(1):1-6.

30. Kornman KS, Crane A, Wang HY, di Giovine FS, Newman MG, Pirk FW, Wilson TG, Higginbottom FL, Duff GW: The interleukin-1 genotype as a severity factor in adult periodontal disease. J Clin Periodontol 1997. 24(1):72-77.

31. Sachidanandam R, Weissman D, Schmidt SC, Kakol JM, Stein LD, Marth G, Sherry S, Mullikin JC, Mortimore BJ, Willey DL, et al: A map of human genome sequence variation containing 1.42 million single nucleotide polymorphisms. Nature 2001, 409(6822):928-933.

32. McGeer PL, McGeer EG: Polymorphisms in inflammatory genes and the risk of Alzheimer disease. Arch Neurol 2001, 58(11):1790-1792.

33. Liu Y, Yang S, Lin AA, Cavalli-Sforza LL, Su B: Molecular evolution of CXCR1, a G protein-coupled receptor involved in signal transduction of neutrophils. J Mol Evol 2005, 61(5):691-696.

34. Papapanou PN, Lindhe J, Sterrett JD, Eneroth L: Considerations on the contribution of ageing to loss of periodontal tissue support. J Clin Periodontol 1991, 18(8):611-615

35. Borrell LN, Papapanou PN: Analytical epidemiology of periodontitis. J Clin Periodontol 2005, 32(Suppl 6):132-158.

36. Stabholz A, Soskolne WA, Shapira L: Genetic and environmental risk factors for chronic periodontitis and aggressive periodontitis. Periodontol 2010, 53:138-153.

37. Tonetti MS: Cigarette smoking and periodontal diseases: etiology and management of disease. Ann Periodontol 1998, 3(1):88-101.

38. Tomar SL, Asma S: Smoking-attributable periodontitis in the United States: findings from NHANES III. National Health and Nutrition Examination Survey. J Periodontol 2000, 71(5):743-751.
39. Grossi SG, Genco RJ, Machtei EE, Ho AW, Koch G, Dunford R, Zambon JJ, Hausmann E: Assessment of risk for periodontal disease. II. Risk indicators for alveolar bone loss. J Periodontol 1995, 66(1):23-29.

40. Okamoto Y, Tsuboi S, Suzuki S, Nakagaki H, Ogura Y, Maeda K, Tokudome S: Effects of smoking and drinking habits on the incidence of periodontal disease and tooth loss among Japanese males: a 4-yr longitudinal study. J Periodontal Res 2006, 41(6):560-566.

41. Pena SD, Di Pietro G, Fuchshuber-Moraes M, Genro JP, Hutz MH, Kehdy Fde S, Kohlrausch F, Magno LA, Montenegro RC, Moraes MO, et al: The genomic ancestry of individuals from different geographical regions of Brazil is more uniform than expected. PLoS One 2011, 6(2):e17063.

42. Parra FC, Amado RC, Lambertucci JR, Rocha J, Antunes CM, Pena SD: Color and genomic ancestry in Brazilians. Proc Natl Acad Sci USA 2003, 100(1):177-182.

43. Pimenta JR, Zuccherato LW, Debes AA, Maselli L, Soares RP, Moura-Neto RS, Rocha J, Bydlowski SP, Pena SD: Color and genomic ancestry in Brazilians: a study with forensic microsatellites. Hum Hered 2006, 62(4):190-195.

doi:10.1186/1477-5751-10-14

Cite this article as: Scarel-Caminaga et al:: Variation in the CXCR1 gene (IL8RA) is not associated with susceptibility to chronic periodontitis. Journal of Negative Results in BioMedicine 2011 10:14.

\section{Submit your next manuscript to BioMed Central and take full advantage of:}

- Convenient online submission

- Thorough peer review

- No space constraints or color figure charges

- Immediate publication on acceptance

- Inclusion in PubMed, CAS, Scopus and Google Scholar

- Research which is freely available for redistribution

Submit your manuscript at www.biomedcentral.com/submit
Biomed Central 